\title{
ESSAY
}

\section{HIRSHMAN, BRONTË, AND HAWTHORNE ON LAW, ABORTION, AND SOGIETY: BRAVA AND ADDENDUM}

\author{
JOHN O. HONNOLD†
}

An essay by Professor Hirshman in a recent issue of this Review made powerful use of literature to probe the social reality of laws prohibiting abortion. 'The current reexamination of woman's constitutional right to end pregnancy calls for bringing all our intellectual resources to bear on this issue. ${ }^{2}$ Hirshman's essay has contributed to this process by examining the position of women in society with powerful summaries of Brontë's Jane Eyre and Hawthorne's The Scarlet Letter. ${ }^{3}$

One purpose of this brava is to alert other readers of the Review to this poignant material and the contribution that it can make to this question: Does requiring women to bring unwanted pregnancy to full term subject them to heavy, unequal, and unjustified burdens? These burdens and the anguish of months and years are hidden from men, and from the great majority of women who have not been through this experience, particularly in settings of abandonment. Hirshman's essay illustrates the evocative power of literature to help others perceive reality that lies beyond their own experience.

Empathic perception of the hurt that male domination can inflict on women in the position of Jane Eyre and Hester Prynne is important, but the pending constitutional issue also calls for the consideration

$\uparrow$ Schnader Professor of Law Emeritus, University of Pennsylvania.

Hirshman, Brontë, Bloom, and Bork: An Essay on the Moral Education of Judges, 137 U. PA. L. REv. 177 (1988) (hereinafter cited by page number).

2 Roe v. Wade, 410 U.S. 113 (1973), is under attack by the petitioners in Webster v. Reproductive Health Services, 851 F.2d 1071 (8th Cir. 1988), cert. granted, 109 S. Ct. 780 (1989), and in an amicus brief filed by the United States Attorney General.

3 Pp. 209-24. Others will disagree, but my own brava does not extend to the use (pp. 224-30) of M. ATwOOD, The HANDMAID's TALE (1985), a futuristic fantasy of recent vintage which scarcely meets Hirshman's "basic criteria for serious literature": works that (1) treat the "permanent and general aspects of human nature and institutions" and (2) have "withstood the test of time" (p. 208). This Comment will not address other aspects of the essay, such as "interpretavism" as a limit on constitutional development (Bork, Ely, and All That), pp. 181-87, and the "Problem of the Relativity of Truth", pp. 188-96, as posed by A. Bloom, The Closing of the American Mind (1987). 
of relevant bodies of social fact. What is the impact of compulsory child-bearing on the nurture and health of the child and on the life and well-being of the mother and other members of the family? What are the social and economic circumstances of the women who wish to terminate pregnancy? Can these women cope with the child-bearing and nurture as well as other segments of society? Do male and female parents make comparable contributions to the support and nurture of children that result from unwanted pregnancy ? $^{4}$ Against a background of centuries of male domination, these questions suggest the basis for a serious case of social and gender discrimination in violation of the equal protection clause of the fourteenth amendment-a case that seems at least as solidly rooted in the Constitution as the "privacy" concept that so far has occupied the center of the stage. ${ }^{5}$

Interplay of legal concept and social fact was a significant issue in the 1954 Brown decision that racial segregation violated the equality guarantee of the fourteenth amendment. Following this decision some of our most brilliant and respected scholars were unable to perceive inequality in laws requiring segregation. ${ }^{6}$ Deeper and more intimate experience with the facts of segregation in its psychological and social setting should have stilled these concerns. ${ }^{\text {? }}$

The suggestion that social facts have a significant role may seem irrelevant or impious to those who find the answer quickly in moral and religious convictions concerning the personhood and spiritual endowment of the fetus from the moment a sperm fertilizes an ovum. These convictions, of course, have a fully protected role in the legislative process. In the legislative setting, opinions on moral and religious issues are fully protected under the free expression guarantees of the first amendment, and opinions based on religious belief are also pro-

- This is not the place to describe the dimensions of the facts that are relevant and the material that is now available. See, e.g., Cates, Legal Abortion: The Public Health Record, 215 ScI. 1586 (1982).

- Professor Tribe reports that ACLU's Reproductive Freedom Project "has long pursued a policy of discouraging sex discrimination claims in abortion cases." $\mathrm{L}$. Tribe, American Constitutional Law 1353 n.109 (2d ed. 1988). This policy seems passing strange, particularly in view of the current Court's problematic response to "go-for-broke" arguments premised on broad concepts not directly rooted in specific constitutional guaranties.

- See, e.g., Wechsler, Toward Neutral Principles of Constitutional Law, 73 HaRv. L. Rev. 1, 34 (1959) ("assuming equal facilities, the question posed by stateenforced segregation is not one of discrimination at all").

7 See Black, The Lawfulness of the Segregation Decisions, 69 YALE L.J. 421, 427 (1960). For conflicting views of the relevance of social science material to broaden perception of the problem, see Cohn, 1954 Annual Survey of American Law: Jurisprudence, 30 N.Y.U. L. REv. 150, 157-158 (1955), and Honnold, Book Review, 33 IND. L.J. 612, 614 (1958). 
tected by the closely related "free exercise" guarantee. On the other hand, giving religious beliefs greater weight than secular opinions violates the first amendment's prohibition of the "establishment of religion". 8

The relevant question is this: If evidence establishes that a law does serious harm to a discrete and disadvantaged group, in constitutional review of whether this harm can be justified, what weight should be given to the opinion of those whose moral values or religious beliefs are furthered by the law? The question is important because these opinions and beliefs provided the principal support of the laws invalidated in Roe v. Wade.

This issue has been latent (but seldom squarely faced) in landmark constitutional decisions. In the Brown decision the Court did not conclude that racial segregation was justified by widely-held opinions and beliefs, including the teaching that blacks were descendants of Noah's son, Ham, whose descendants were under a divine curse. ${ }^{9}$ The laws of sixteen states prohibiting racial intermarriage were invalidated in the face of widespread community abhorrence of intermarriage supported by the belief, articulated by the trial judge, that "Almighty God ... did not intend for the races to mix."10 Also ineffective in constitutional review were widely held opinions that artificial methods of contraception were immoral and violations of religious teaching. ${ }^{11}$ On the other hand, the Court in a 1986 decision (5-4) relied heavily on community opinions as to morality and religion in sustaining prohibitions of private homosexual conduct ${ }^{12}$ - a problem that (like the current attacks on Roe $v$. Wade) could have profited by help from great literature and from medical and social facts in perceiving significant dimensions of the human condition.

B See Stone v. Graham, 449 U.S. 39, $41-42$ (1980). But cf. Bowers v. Hardwick, 478 U.S. 186, 196-97 (1986) (Burger, C.J., concurring) (noting the emphasis on "Judeo-Christian moral and ethical standards" and the prohibitions developed "when powers of the ecclesiastical courts were transferred to the King's Courts").

- Genesis 9:25. The curse was based on Ham's violation of a sexual taboo when he "saw the nakedness of his father"; the curse was to be "a servant of servants... unto his brethren." Id.

10 Loving v. Virginia, 388 U.S. 1, 3 (1967).

11 See Griswold v. Connecticut, 381 U.S. 479 (1965), overruling State v. Griswold, 200 A.2d 479, 480 (Conn. 1964).

12 Bowers v. Hardwick, 478 U.S. 186 (1986). The majority opinion by Mr. Justice White gave hints of special pressures from public concern that the Court based decisions on its own views of social policy - a concern that is plausible when counsel and Court do not forcefully present the social facts exposing the social and personal consequences of insensitive attempts at social control. 
In closing, a warning: Hirshman's essay roused this old professor, for good or ill, to thought. Beware of what this essay and its agonizing problems can do for younger minds! ${ }^{13}$

${ }^{13}$ If ideas in this brava seem stale, perhaps this can be excused by a decade of foreign adventures after decades of teaching and writing on constitutional law with a special concern for the anti-discrimination guarantees of the fourteenth amendment. 